\title{
Charcot, Mitchell and Lees: neurology free thinkers and their experiences of psychoactive drugs
}

\author{
Charcot, Mitchell e Lees: livres-pensadores da neurologia e suas experiências com drogas \\ psico-ativas
}

Hélio A. G. Teive1, Francisco M.B. Germiniani', Pedro A. Kowacs², Renato P. Munhoz

\begin{abstract}
Three world-famous neurologists, Charcot and Mitchell, in the $19^{\text {th }}$ century, and Lees, in this century, all of whom had great scientific curiosity, experimented with the psychoactive drugs hashish, mescal and yagé, respectively, in an attempt to increase their knowledge of neurological diseases and how the brain works.
\end{abstract}

Keywords: neurology; psychotropic drugs, brain.

\section{RESUMO}

Três mundialmente famosos neurologistas, Charcot e Mitchell, no século XIX, e Lees neste século, tiveram eles mesmos, experiências com drogas psico-ativas, com haxixe, mescalina e yagé, respectivamente, demonstrando a sua intensa curiosidade científica, na tentativa de aprimorar o seu conhecimento da função cerebral e das doenças neurológicas.

Palavras-chave: neurologia; psicotrópicos; encéfalo.

The relationship between neurology and the use of psychoactive drugs is the subject of widespread discussion nowadays. Various articles have addressed the neurological complications induced by illicit abuse of drugs such as opioids, psychostimulants, marijuana, sedatives, hallucinogens, inhalants and related agents ${ }^{1}$. Much attention has been dedicated to the intrinsic mechanisms involved in the transition from the recreational use of drugs to progressive addiction ${ }^{2}$. Furthermore, there is a plethora of studies on the medical use, particularly in neurology, of certain psychoactive drugs, such as cannabis and cannabinoids ${ }^{3}$. This complex context includes historical references to the use of certain psychoactive drugs by famous neurologists to study and record the effects of these substances for themselves. Here, we briefly discuss Jean-Martin Charcot's and Silas Weir Mitchell's personal explorations with psychoactive drugs in the $19^{\text {th }}$ century and Andrew J. Lees' similar ventures in the $21^{\text {st }}$ century.

\section{JEAN-MARTIN CHARCOT AND HASHISH}

Jean-Martin Charcot (1825-1893) is considered the founding father of neurology, as well as the first professor of nervous system diseases ${ }^{4}$ (Figure 1), His contributions to the descriptions of several nervous system disorders are world famous. He studied a wide range of neurological diseases, including amyotrophic lateral sclerosis (Charcot's disease), multiple sclerosis, Charcot-Marie-Tooth disease, tabetic arthropathy, Parkinson's disease and hysteria ${ }^{4,5}$. His biographers described him as having an austere presence and reserved manner and being shy and economic in his gestures with an impenetrable, impassive face and authoritarian personality. Charcot also had a great interest in bizarre, supernatural and exotic behaviors ${ }^{4,5}$. In 1853 , he and a fellow medical student tried smoking hashish to understand the effect of this drug and the sensation of insanity it produced ${ }^{4,5}$. Henry Meige published a description of Charcot's hashish

\footnotetext{
1Universidade Federal do Paraná, Hospital de Clínicas, Departamento de Medicina Interna, Serviço de Neurologia, Unidade de Distúrbios dos Movimentos, Curitiba PR, Brasil;

${ }^{2}$ Universidade Federal do Paraná, Hospital de Clínicas, Serviço de Neurologia, Unidade de Dor de Cabeça, Curitiba PR, Brasil;

${ }^{3}$ University Health Network, Toronto Western Hospital, Gloria and Morton Shulman Movement Disorders, Toronto, ON, Canada.

Correspondence: Hélio A. G. Teive; Rua General Carneiro, 1103 / 102; 80060-150, Curitiba PR, Brasil; E-mail: hagteive@mps.com.br

Conflict of interest: There is no conflict of interest to declare.

Received 14 August 2016; Accepted 05 September 2016.
} 
experiment in 1898, in which he emphasized Charcot's illusions and hallucinations in the following excerpt ${ }^{6}$ :

"...the words become illegible; the strokes of the letters lengthen, twist upon themselves... are transformed into petals of flowers and snatches of architecture... The entire page is covered in drawings: monstrous dragons, grimacing chimeras, incoherent people in a fantastic whirlpool, which recalls the apocalyptic compositions of van Bosch or Jacques Callot" ${ }^{6}$.

Charcot's drawing produced under the influence of hashish is shown in Figure 2.

\section{SILAS WEIR MITCHELL AND MESCAL}

Silas Weir Mitchell (1829-1914) was a very famous and celebrated neurologist in the United States of America and made important contributions to the development of $19^{\text {th }}$ century neurology 5 (Figure 3). Among his seminal works are the description of causalgia (complex regional pain syndrome), phantom limb and nerve injuries, as well as studies in neuropharmacology and neurotoxicology ${ }^{5}$. He was involved in the opening of the first neurological hospital in Philadelphia, in the USA, and in the foundation of the American Neurological Association, of which he was the first elected president, in spite of never having had a university professorship ${ }^{5}$. Silas Weir Mitchell was also a prolific and renowned writer of novels and short stories ${ }^{5}$. In 1895, at an American Neurological Society meeting, he gave a description of the effects he experienced after ingesting mescal, which was published in 1896 in the British Medical Journal

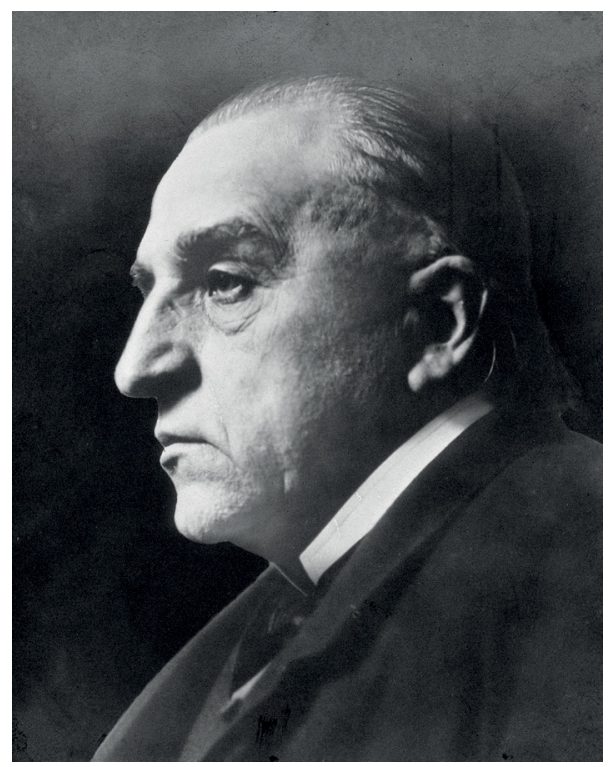

(Reproduced from Google Images: Partíceps, October, 12th, 2016) Figure 1. Jean-Martin Charcot (1825-1893). as "Remarks on the Effects of Anhelonium Lewinii (the mescal button)" (Figure 4). In this report he described several times his impressions of mescal intoxication, including gastric discomfort, flushing of the face, dilated pupils, a sense of exhilaration, a tendency to talk, a pleasing sense of languor, yawning at times and some frontal pain ${ }^{7}$. He described another episode as follows:

"My first vivid show of mescal colour effects came quickly. I saw stars, and then, of a sudden, here and there delicate floating films of colour - usually delightful neutral purples and pinks. These came and went - now here, now there. Then an abrupt rush of countless points of white light swept across the field of view... Then I began to see zigzag lines of very bright colours, like those seen in some megrims..." 7 .

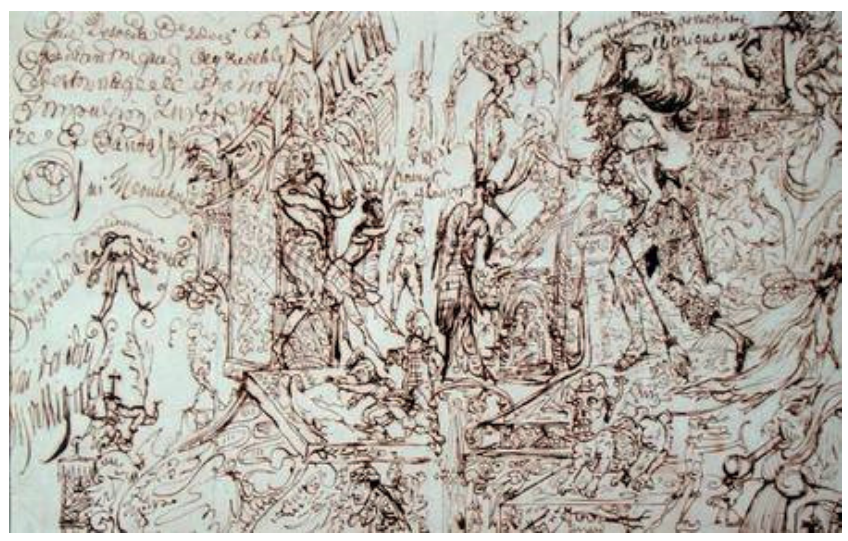

(Reproduced from Google Images: Art Prints, October, 12th, 2016)

Figure 2. Charcot's drawing produced under the influence of hashish.

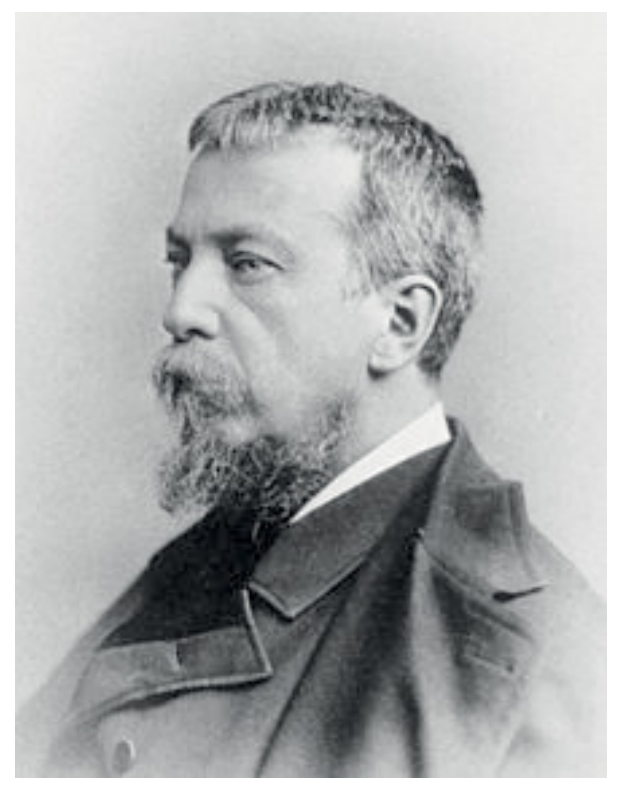

(Reproduced from Google Images: Wikipedia, October, 12 $\left.{ }^{\text {th }}, 2016\right)$. Figure 3. Dr. Silas Weir Mitchell (1829-1914). 


\section{ANDREW J. LEES AND YAGÉ (AYAHUASCA)}

Andrew J. Lees (1947 - ) is a professor of neurology at the National Hospital for Neurology and Neurosurgery, Queen Square, London, and the University College London, in the United Kingdom ${ }^{8}$ (Figure 5). He is a world-famous neurologist and neuroscientist with a dedicated interest in the movement disorders field, having received several awards, including the American Academy of Neurology Lifetime Achievement Award, the Association of British Neurologists Medal, the Dingebauer Prize for Outstanding Research and the Gowers Medal ${ }^{8}$. Throughout his prolific career, he has published over 600 papers, including an outstanding number of masterpieces in the field of movement disorders, particularly Parkinson's disease. Professor Lees is considered the world's most highly cited Parkinson's disease researcher9. Among his most cited works on Parkinson's disease are “Ageing and Parkinson's disease: substantia nigra regional selectivity”, published in 1991, "Accuracy of clinical diagnosis of idiopathic Parkinson's disease: a clinico-pathological study of 100 cases", published in 1992, and "The relevance of the Lewy body to the pathogenesis of idiopathic Parkinson's disease", published in $1998^{10}$. He has authored several books, including Ray of Hope; The Hurricane Port - A Social History of Liverpool; William Richard Gowers 1845-1915 - Exploring the Victorian Brain; and Mentored by a Madman: The William Burroughs Experiment, published in $2016^{8}$ (Figure 6). This last publication describes a "new journey of radical empiricism, with new scientific perspectives", that chronicles an excursion to the Colombian Amazon Forest during which

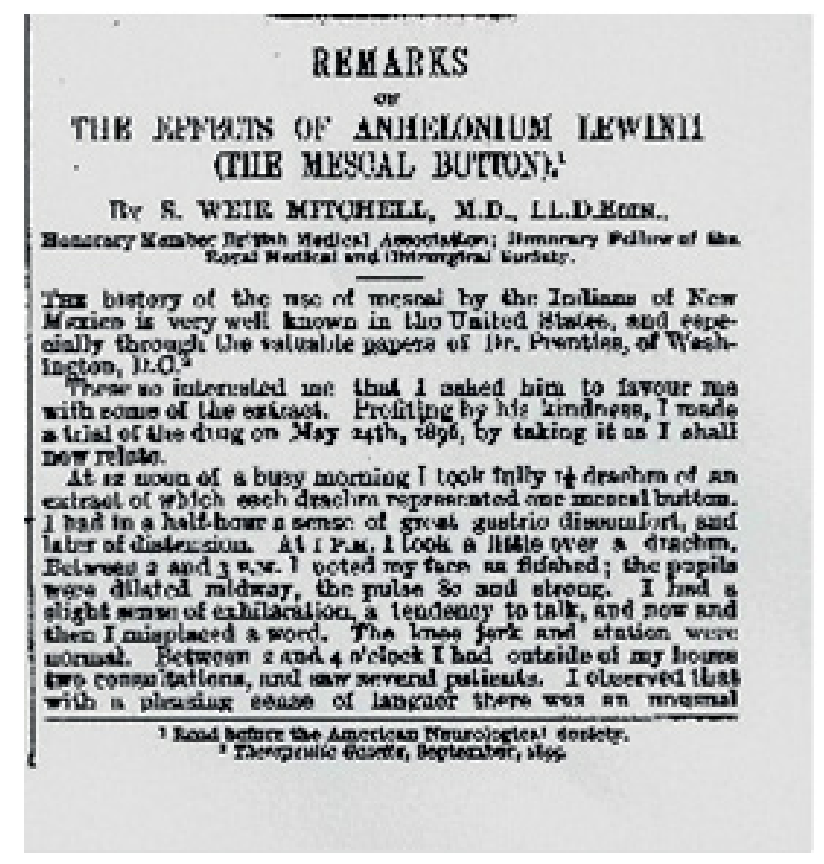

(Reproduced from British Medical Journal, 1896)

Figure 4. Mitchell's paper about the effects of mescal. he experienced a "yagé trip". He drank the sour dark liquid and then described an intense nausea associated with motion sickness and a "near death" sensation". He wrote:

"A soft whistling incantation breaks the silence. Yellow and green iridescent zigzag spectra and indigo and argent helices are under my eyes, ultramarine charges come out of my arms.... The flashes of beauty intensify as I stagger from the lodge... Phosphenes, coiled floating chains and aerolitos flash above me. Images unwind from the windmills of my mind"s.

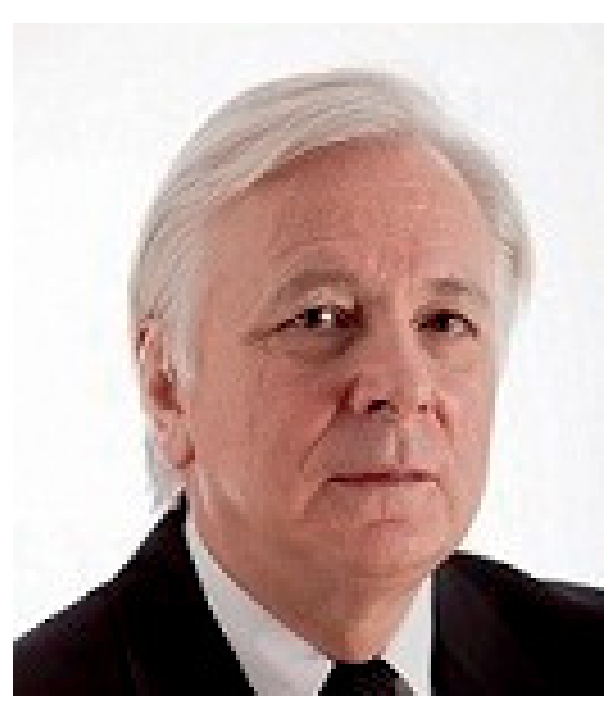

(Reproduced from Google Images: UCL, October 12th, 2016) Figure 5. Professor Andrew J. Lees (1947 - ).

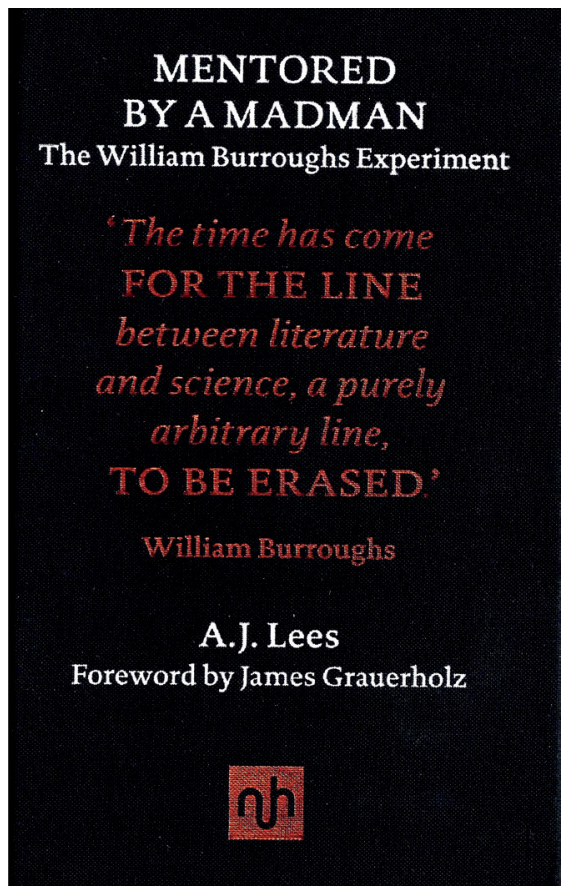

(Reproduced from the authors's book)

Figure 6. Lees' published book about the William Burroughs Experiment. 
In conclusion, driven by deep scientific curiosity, the descriptions of the altered perceptual states under the influence of psychoactive drugs hashish, mescal, and yagé by these three famous neurologists, can be seen as experiments and neuroscientific-biased windows into their pharmacological and behavioral effects in the human brain.

\section{Acknowledgments}

The authors thank Professor Andrew J. Lees (UCL, Institute of Neurology, National Hospital for Neurology and Neurosurgery, Queen Square, London, UK) who made a critical review of this manuscript.

\section{References}

1. Brust JC. Neurologic complications of illicit drug abuse. Continuum (Minneap Minn) 2014;20(3 Neurology of Systemic Disease):642-56. doi:10.1212/01.CON.0000450971.99322.cd

2. Pascoli V, Terrier J, Hiver A, Lüscher C. Sufficiency of mesolimbic dopamine neuron stimulation for the progression to addiction. Neuron. 2015;88(5):1054-66. doi:10.1016/j.neuron.2015.10.017

3. Benbadis SR, Sanchez-Ramos J, Bozorg A, Giarratano M, Kalidas K, Katzin L et al. Medical marijuana in neurology. Expert Rev Neurother. 2014;14(12):1453-65. doi:10.1586/14737175.2014.985209

4. Goetz GG, Bonduelle M, Gelfand T. Charcot: constructing neurology. New York: Oxford University Press; 1995.

5. Goetz GG. Jean-Martin Charcot and Silas Weir Mitchell. Neurology. 1997;48(4):1128-32.
6. Meige H. Charcot artiste. Nouvelle Iconographie de la Salpêtriére. 1898;11:489-516.

7. Mitchell SW. Remarks on the effects of anhelonium lewinii (the mescal button). Br Med J. 1896;2(1875):1625-9.

8. Lees AJ. Mentored by a madman: the William Burroughs experiment. London: Nothing Hill; 2016.

9. Sorensen AA, Weedon D. Productivity and impact of the top 100 cited Parkinson's disease investigators since 1985. J Parkinsons Dis. 2011;1(1):3-13. doi:10.3233/JPD-2011-10021

10. Ponce FA, Lozano AM. The most cited works in Parkinson's disease. Mov Disord. 2011;26(3):380-90. doi:10.1002/mds.23445 